\title{
Enigmatic encrusting fossils from the Upper Devonian of Russia: probable Rothpletzella microproblematica preserved in three dimensions
}

\author{
Michał Zatoń $^{a^{*}} \&$ Emilia Jarochowska ${ }^{b}$
}

${ }^{a}$ University of Silesia in Katowice, Faculty of Earth Sciences, Będzińska 60, 41-200

Sosnowiec,Poland,e-mail:mzaton@wnoz.us.edu.pl

${ }^{b}$ GeoZentrum Nordbayern, Friedrich-Alexander-Universität Erlangen-Nürnberg, Erlangen,

Germany,e-mail: emilia.jarochowska@fau.de

*Corresponding author: mzaton@wnoz.us.edu.pl

\begin{abstract}
Intriguing microfossils encrusting certain Upper Devonian brachiopod shells from the Central Devonian Field, Russia, are reported for the first time. The fossils are pyritized, have fan-shaped morphologies and are formed by tightly-packed branches which divide dichotomously at different points in their development. The organisms preserved grew horizontally on shelly substrates. Comparisons with similar fossils known from the literature indicate that they do not represent any animal taxon commonly encrusting hard substrates. Instead, the morphology, organization and growth mode of these fossils are most similar to microfossils known under the name Rothpletzella, which so far have only been known from thin sections. Rothpletzella is a problematicum for which algal affinities have been proposed. The preserved branches of the fossils described here are too large for cyanobacterial cells. Their large size suggests their placement, along with other described Rothpletzella fossils, within the green algae order Bryopsidales. It is suggested that originally, these organisms
\end{abstract}


possessed thalli encased within a thin, delicate calcified sheath. After burial the thalli underwent pyritization via sulphate reduction mediated by bacterial activity within low $\mathrm{pH}$, dysoxic microenvironment, and their sheath dissolved. As three-dimensionally preserved, these algae provide a new, previously unrecognized, component within the Devonian encrusting communities.

Key words: Epibionts; Frasnian; algae; pyritization; palaeoecology. 


\section{Introduction}

Encrusters, organisms inhabiting hard substrates through cementation, are a common constituent of both fossil and Recent marine environments. Many encrusting groups have an excellent fossil record owing to the calcitic mineralogy of their skeletons (e.g., Taylor and Wilson 2003). Cementing to hard substrates such as shells or rocks, encrusters are always preserved in situ with respect to their substrates, making them ideal objects for palaeoecological studies, including niche differentiation (cryptic vs. open surfaces, such as discussed in Kershaw 1980; Palmer and Fürsich 1974; Vinn and Wilson 2012a, b; Zatoń et al. 2018), ecological succession (e.g., Wilson 1985, 1986, 1998; Wilson and Taylor 2001; Schlögl et al. 2008; Zatoń et al. 2011) and competition (e.g., Liow et al. 2016, 2017) through time.

During the Devonian, encrusting organisms were very common due to the presence of a variety of suitable substrates, especially in the form of abundant and diverse corals and brachiopods (e.g., Alvarez and Taylor 1987; Baird and Brett 1983; Bordeaux and Brett 1990; Zapalski 2005; Schneider 2013; Zatoń et al. 2015, 2017, 2018), as well as lithic hardgrounds and cobbles (e.g., Baird 1976, 1981; Zatoń et al. 2014). Compared with Mesozoic encrusting communities, those in the Palaeozoic, exemplified by Devonian assemblages, differed much in their taxonomic composition. In general, they were represented by many extinct groups, the taxonomic affinities of which are still uncertain. These include encrusters such as conical cornulitids (e.g., Vinn et al. 2018), spirorbiform microconchids (e.g., Taylor and Vinn 2006; Zatoń and Vinn 2011), 'bryozoan'-like hederelloids (Taylor and Wilson 2008), colonial ascodictyids (Olempska and Rakowicz 2014; Wilson and Taylor 2014) or sphenothallids (e.g., van Iten et al. 1992; Neal and Hannibal 2000; Vinn and Kirsimäe 2015). 
The deposits of the Main Devonian Field and Central Devonian Field areas in Russia are well known for their rich fossil content and diverse hard substrates hosting rich encrusting assemblages, including fossils of uncertain affinities listed above (Hecker 1983; Zatoń and Krawczyński 2011; Zatoń et al. 2017). Careful examination of brachiopod shells from the Upper Devonian of the Central Devonian Field, however, revealed the presence of intriguing, fan-shaped encrusters which have not been previously reported. Therefore, the aim of the present paper is to describe these enigmatic fossils, compare them to other similar forms and discuss their probable biological affinities.

\section{Material and methods}

\section{Material provenance}

The material was collected from the Upper Devonian deposits of the southern part of the Central Devonian Field in western part of Russia (Fig. 1A) during joint Polish-Russian field trips in 2002 and 2012. A major collection of specimens was found on brachiopod shells from the locality of Khlevnoe during the 2012 field campaign. The Khlevnoe locality is

situated ca. $40 \mathrm{~km}$ north of the city of Voronezh and ca. $20 \mathrm{~km}$ south of the city of Zadonsk in the Don River Valley (N 52.172983; E 39.077089º). One specimen was also found encrusting a brachiopod shell during the 2002 field campaign. It was derived from the stratigraphically-equivalent deposits which crop out in the huge quarry at southerly located Krivobor'e, situated just between the Zadonsk and Voronezh cities (N 52.045850 ; E 39.137847 ; Fig. 1B). As the majority of specimens come from Khlevnoe where they were collected straight from the outcrop, that section is presented here. The Upper Devonian 
deposits at Khlevnoe consist of 9 m-thick, shallow marine, upper Frasnian limestones, marly limestones, marlstones and subordinate clays (Sokiran 2002; Filipiak and Zbukova 2006) (Fig. 2). The deposits represent the regional Evlanovo Horizon corresponding to the Upper rhenana standard conodont Zone (see Sokiran 2002) and the Aurora speciosa (AS) miospore Subzone of the Cristatisporites deliquescens-Verrucosisporites evlanensis (DE) miospore Zone (Filipiak and Zbukova 2006). The deposits at Khlevnoe and Krivobor'e are dominated by brachiopods and are rich in gastropods, tabulate and rugose corals, as well as various encrusting taxa. The encrusted brachiopod fauna is represented mainly by spiriferids (Cyrtospirifer, Theodossia), atrypids (Variatrypa) and productids (Donalosia), as well as subordinate orthotetids (Schuchertella) (Sokiran 2002; Zatoń and Krawczyński 2011; Zatoń et al. 2017).

\section{Methods}

Following gentle cleaning of the brachiopod shells, encrusting fossils were inspected using a Leica Wild M10 binocular microscope equipped with a Nikon NikCam Pro1 camera for morphological observation and photographic documentation. Then the eight best preserved specimens were selected for further detailed observation under an environmental scanning electron microscope (ESEM) Philips XL30 housed at the Faculty of Earth Sciences in Sosnowiec, Poland. The specimens were examined in an uncoated state under low vacuum conditions. Images were generated using backscattered electrons (BSE detector).

The specimens are housed at the department of Paleontology and Stratigraphy, Faculty of Earth Sciences in Sosnowiec, abbreviated GIUS 4-3681.

Reference thin sections with the problematicum Rothpletzella gotlandica from the Eke Formation (Ludfordian, upper Silurian) in Gotland have been photographed using Zeiss Axio 
Zoom V16 fitted with an Axiocam 506 camera. The thin sections are stored in the collections of A. Munnecke, GeoZentrum Nordbayern, Friedrich-Alexander-Universität ErlangenNürnberg, under the identifier AM124.

\section{Description of the fossils}

Careful searching through the encrusted shells provided twenty enigmatic encrusting fossils (nineteen from Khlevnoe and one from Krivobor'e). These fossils have been found preserved on external surfaces of fourteen shells belonging to the following species: Cyrtospirifer (twelve encrusting specimens), Variatrypa (five specimens), Donalosia (one specimen), Schuchertella (one specimen) and Theodossia (one specimen).

The fossils have a fan-shaped appearance, either consisting of a single fan or a few lobes growing outwards in different directions (Fig. 3). The fossils are tiny (up to $2.5 \mathrm{~mm}$ width), a single lobe having on average only $1 \mathrm{~mm}$ in width. The surface of the lobes bears prominent longitudinal grooves running parallel to each other, separating them on distinct, but tightly grouped, wider branch-like structures (Figs 3-4). In some points, however, the branches bifurcate, producing secondary branches which further divide on another two, separate branching structures. The particular branches are straight or gently curved (Fig. 4EH). They widen toward the bifurcation point Fig. 4F-H), where their width ranges from 74 up to $176 \mu \mathrm{m}(\mathrm{n}=44)$. The width of a single branch following bifurcation ranges from 37 up to 88 $\mu \mathrm{m}(\mathrm{n}=52)$. The width of both branches at the bifurcation points and the width of a single branch following a bifurcation varies widely within the same specimen (see Appendix 1). The angle at which secondary branches bifurcate from the main branch varies from $10^{\circ}$ to $30^{\circ}$ $(\mathrm{n}=50)$. In some specimens a pointed origin is visible, marking the beginning of the colony growth (Fig. 4A). 
All encountered specimens are pyrite internal moulds (Fig. 4). Some specimens are preserved only by euhedral crystals while others by both euhedral crystals and pyrite framboids (see, e.g., Fig. 4D, H). Pyrite framboids have large sizes, ranging from 10 to $20 \mu \mathrm{m}$ in diameter. Two specimens are preserved in the form of iron oxide/oxyhydroxide due to pyrite weathering, which is evidenced by their yellow-brown stain (Fig. 3A). Due to such coarse-grained pyritization, any external features which might have been present, are currently obliterated. Some convexity of the branches, however, is still preserved which indicate that originally they were thick, three-dimensional and not flat, mat-like structures.

\section{Discussion}

\section{Comparisons and affinities of the fossils}

The fossils described here represent the remains of genuine encrusting organisms. It is clearly evidenced in their life habit, growth mode and state of preservation (Figs 3-4). All specimens are firmly attached (cemented) to the shelly substrates and some specimens overgrow (Fig. 3D) or are overgrown by other encrusters (Fig. 4C) preserved on the same brachiopod shells. One example shows one fan encrusting another (Fig. 4C). The particular branch-like structures run evenly and tightly associated to each other. They do not show any evidence of mutual overlapping or curling, which would suggest that the organisms originally grew vertically and became flattened on the substrate post-mortem and after burial.

On the grounds of the state of preservation and size, the fossils described here may be clearly distinguished from such superficially similar Palaeozoic fossil organisms such as noncalcareous algae Perissothallus (Krings et al. 2007) and putative hydrozoan Caledonicratis 
(Zapalski and Clarkson 2015). Perissothallus from the Carboniferous of USA and Germany may be somewhat similar to the fossils described here in its fan-shaped organization of the thalli when preserved on bedding-plane. However, its thalli are several times larger and possess loosely arranged, bifurcating segments. Moreover, its preservation in the form of carbonaceous thalli showing curled and overlapping segments indicates that, originally, it was a vertically-growing alga (see Krings et al. 2007). The hydrozoan-like Caledonicratis from the Carboniferous of Scotland also possesses bifurcating branches; however, these are also significantly larger (up to $10 \mathrm{~mm}$ in length), ramified and have rounded tips. Despite their phosphatic mineralogy (originally chitinous?), the general morphology and arrangement of the fossils (some found attached to the shrimp carapaces, some scattered on the bedding planes) may indicate that Caledonicratis was a vertically-growing organism.

The fan-shaped fossils may be also somewhat similar with respect to their size and general appearance to the ichnotaxon Dendrina of a rosette morphology, such as Dendrina dendrina or Dendrina belemniticola. However, in closer inspection the 'branches' (galleries) of the latter species are more irregular and loosely arranged (see, e.g., Wisshak 2017; Wisshak et al. 2017). Moreover, it is a bioerosion trace and hence produced within the lithic substrate by a boring organism, while the fan-shaped fossils from the Upper Devonian discussed herein are remnants of body fossils left by encrusting organisms.

Searching through the literature, we have not found any encrusting fossils which would be identical or, at least, similar with respect to the external morphology to those reported in the present paper. However, we noticed that the fossils discussed herein are similar to some microfossils which so far have only been detected in thin sections. These microfossils have been found encrusting Silurian and Devonian stromatoporoids (Wood 1948; Johnson 1964) and assigned to the genus Rothpletzella by Wood (1948). It is worth noting that previously Rothpletzella, together with two other associated microfossils (Girvanella and 
Wetheredella), have been described under a single taxon called Sphaerocodium and considered as an alga by Rothpletz (1890). Maslov (1956) gave Rothpletzella a different name, Coactilum, which has been considered as its junior synonym (e.g., Johnson 1964; Liu et al. 2016).

Although Rothpletzella fossils are known only from thin sections, both the Rothpletzella and the three-dimensionally preserved Upper Devonian encrusters described here share very similar morphology and mode of growth. Like the Upper Devonian encrusters from Russia, Rothpletzella is also an encrusting fossil having a fan-shaped morphology consisting of branches (filaments, see Wood 1948) which bifurcate in different points during ontogeny (Fig. 5). Noticeably, like in the Upper Devonian forms discussed herein, in Rothpletzella the bifurcating branches keep in contact along their inner margins (see Wood 1948, p. 19, pl. 2B; see also Fig. 5). According to observations of Wood (1948) and Johnson (1964), the branching filaments are also non-septate. However, the main difference between Rothpletzella and our specimens is the size of the branches (filaments). According to Wood (1948), the filaments of Silurian forms from Gotland (Sphaerocodium type collection of Rothpletz) measured up to $40 \mu \mathrm{m}$ in width (Fig. 6). Johnson (1964) compiled data on dimensions proposed to distinguish four species of Rothpletzella. Maximum filament diameter of $40 \mu \mathrm{m}$ has been reported in $R$. straeleni Lecompte, 1936, and R. gotlandica Wood, 1948. Riding and Soja (1993), however, questioned the division into multiple species based on their observations of Rothpletzella from the Silurian of Alaska, where they observed a continuum of values across ranges reported for all previously proposed species. They placed the specimens, ranging in filament breadth from 13 to $37 \mu \mathrm{m}$, in the type species $R$. gotlandica. This approach is adopted here. Our comparison with Silurian Rothpletzella also showed that the width of its branches at and after the bifurcation points are substantially (two to three times) smaller than in the Upper Devonian specimens (see Appendix 1). The width before 
bifurcation was $29-77 \mu \mathrm{m}(\mathrm{n}=72)$ and after bifurcation $16-37 \mu \mathrm{m}(\mathrm{n}=61)$. The angle between bifurcations ranged from $16^{\circ}$ to $55^{\circ}$ with an average of $34^{\circ}(n=40)$. In the Upper Devonian encrusters described here, the angle ranged from $10^{\circ}$ to $30^{\circ}$.

Similarities in terms of life habit, environment, colonized substrates and branching patterns warrant a discussion of potential affinities between Rothpletzella and the Upper Devonian material described here. Rothpletzella is a problematic taxon. As has already been indicated by Wood (1948, p. 17), the size of the branching filaments is below that of any multicellular animals. The lack of any orifices may also attest against any affiliation with benthic, encrusting animals. The absence of septation led Wood (1948) to suggest that Rothpletzella could be an alga belonging to blue-green algae (Cyanobacteria) or to Siphonales (an obsolete order within Ulvophyceae, close to Bryopsidales). Similarly, Johnson (1964) considered it as an alga of uncertain affinities, possibly belonging to blue-green or green algae. Wray (1977) considered it, under the name Sphaerocodium, as a blue-green alga, as well. Other authors (e.g., Riding and Soja 1993; Liu et al. 2016) regarded it as a microproblematicum. Although Early Palaeozoic corallines and coralline-like algae were sporadically described (see Brooke and Riding 1998; Riding et al. 1998; Feng et al. 2010), the lack of any reproductive organs-containing cavities or pores (conceptacles; see, e.g., Braga 2003) in the Upper Devonian and other specimens of Rothpletzella published in the literature, exclude them from representing the non-geniculate coralline algae.

The small size of filaments, absence of any external apertures or orifices (suggesting assimilation over the whole surface; see Wood 1948), the lack of septa, high abundance in shallow, tropical and warm-temperate successions, congruent with the role of a primary producer, and the tendency to form thick coating on and around the substrate (Fig. 5C), together suggest that Rothpletzella may be a photosynthesizing organism which had more in common with algae than with any animal organisms. Within the Cyanobacteria, branching of 
the filamentous forms is an important taxonomic criterion (Golubić et al. 1996). Branching as present in Rothpletzella corresponds to V-branching, a type of true branching produced by longitudinal and oblique cell divisions. True branching is constrained to Subsection V of current bacteriological classification (Castenholz 2001) or the formerly recognized order Stigonematales (Anagnostidis and Komárek 1990). Although cyanobacteria with true branching have been shown to be polyphyletic since the introduction of these classifications (Gugger and Hoffmann 2004; Hoffmann et al. 2005), within this class, branching phenotypes akin to those in Rothpletzella are constrained to a fairly narrow group of taxa within the former Stigonematales. Assignment of Rothpletzella to Stigonematales or a morphologically similar, extinct group of cyanobacteria is at a potential contradiction with including the Upper Devonian material in this genus, because of size constraints of cyanobacterial cells. The largest size of $100 \mu \mathrm{m}$ reported in cyanobacteria was found in Oscillatoria, a non-branching, filamentous, free-living freshwater genus. More typical for large cells are diameters up to 60 $\mu \mathrm{m}$, found in, for example, Stigonema (Nielsen 2006; Schulz-Vogt et al. 2007). In cyanobacteria, strict biomechanical constraints limit the diameter of a single cell: diffusion and absorption cross section (Niklas 1994, 1997). With increasing cell size, both the efficiency of harvesting incident light and the rate of passive diffusion decreases - two processes most important for photosynthetic organisms to acquire light energy and $\mathrm{CO}_{2}$, and transport them within the cell. On these grounds, it is very unlikely that cyanobacteria as large as the Upper Devonian fossils described here could have existed.

Much larger sizes in marine algae are afforded by the cytoskeleton and motor proteins present in eukaryotic cells, which evade some of the limitations imposed by passive diffusion. The branching, aseptate morphology of the fossils newly described here and of Rothpletzella is comparable with siphonous growth found in two extant sister chlorophyte groups, the Bryopsidales and Dasycladales (Leliaert et al. 2012). These algae build macroscopic, 
morphologically differentiated coenocytes - multinucleate thalli resulting from cell divisions occurring in the absence of cytokinesis. The formation of coenocytes is made possible by cytoskeleton adaptations which permit efficient intercellular transport. Both orders have fossil records extending back to the Palaeozoic.

Based on the encrusting habit and lack of radial symmetry, we exclude a dasyclad affinity of Rothpletzella and the specimens presented here. Calcifying, filamentous and bifurcating forms growing on hard substrates occur in extant Bryopsidales and, based on these morphological features, Palaeozoic fossils have been previously assigned to this order. Examples include Ortonella, Hedstroemia, Cayeuxia, Garwoodia, Bevocastria and, potentially, Palaeoporella (Johnson et al. 1959; Johnson 1961). Wray (1977) included these genera in putative cyanobacteria based on the lack of sufficient evidence for their affinity with eukaryotes and the similarity with the cyanobacterium Scytonema. In most of these fossils cell diameters are below $100 \mu \mathrm{m}$ (e.g. Wray, 1977), but they range up to $180 \mu \mathrm{m}$ in, for example, Hedstroemia (Johnson et al. 1959). This distribution of sizes corresponds to that in modern Bryopsidales, where most filamentous forms are thinner than $100 \mu \mathrm{m}$, but macroscopic coenocytes are common and can reach metre-scale dimensions (Raven 1999).

The diversity and abundance of potential calcifying, filamentous fossils with putative bryopsidalean affinity during the Palaeozoic is supported by molecular clock methods calibrated with the fossil record. They indicate a diversification of siphonous algae during the Palaeozoic (Verbruggen et al., 2009). However, within Bryopsidales, there is no indication of calcification prior to the appearance of Halimedaceae and Udoteaceae in the Permian Period. Therefore, calcified algae discussed as potential members of Bryopsidales might represent an extinct calcifying group.

In summary, new Upper Devonian encrusters might, based on their growth form, represent Rothpletzella fossils preserved in three dimensions and with extremely wide 
filaments. This, however, would invalidate the cyanobacterial affinity discussed for this genus. The new material described here is too large for cyanobacteria and must have an eukaryotic affinity. The environmental distribution and growth habit of Rothpletzella support its phototrophic mode of feeding. If the new specimens are included in this genus, then combined information on its ecological role of an alga with the large size suggests the placement of Rothpletzella within Bryopsidales.

\section{Taphonomy and ecology of the fossils}

Such encrusting fossils as described here have never been reported from any hard substrates. This may be due to their tiny sizes and delicate nature of the colonies which probably did not fossilize easily. In the present case, despite a large collection of the upper Frasnian and lower Famennian brachiopod shells from the Central Devonian Field (see Zatoń et al. 2017), only twenty specimens were found. These were only encountered on shells from the upper Frasnian deposits. Taking into account such a small number of specimens in comparison to hundreds of other associated encrusters present on the same shelly substrates, it is probable that these putative Rothpletzella encrusters might have been a rare component of the Upper Devonian hard substrate communities and/or their fossilization potential was low. Indeed, unlike the rest of the associated encrusters, which have calcitic skeletons, the thalli of our putative Rothpletzella epibionts were preserved exclusively as pyrite moulds. Interestingly, all Rothpletzella colonies which have been recognized in thin sections and reported in the literature so far are calcitic and thus referred to as calcified microproblematica by some authors (e.g., Riding and Soja 1993; Liu et al. 2016). This dual preservation mode does not necessarily mean that originally the sheath of Rothpletzella thalli had different composition and under specific circumstances were calcified or pyritized. It is more likely 
that the Upper Devonian forms were originally calcified, too, but their calcified sheaths underwent dissolution after pyrite internal moulds had formed.

Both cyanobacteria and Bryopsidales produce calcified sheaths, the composition of which is influenced by the mineralogy of ambient seawater (Arp et al. 2001; Ries 2009; Stanley et al. 2010). During the Devonian Period, seawater chemistry kinetically favoured the precipitation of the calcite polymorph of $\mathrm{CaCO}_{3}$ over the aragonitic polymorph (Sandberg 1983; Hardie 1996). Calcite is more stable and less likely to become dissolved during diagenesis. However, experiments on extant bryopsidaleans indicate that growth in conditions favouring calcite results only in partial substitution of aragonite with calcite in the calcified sheath. In this context, it is likely that the skeleton was a mixture of two or more carbonate polymorphs. Furthermore, even for a given polymorph composition, the crystallographic texture plays an important role in determining the diagenetic stability of a skeleton. Päßler et al. (2018) documented poorly ordered, weak parallel arrangement of crystals with a nearly random distribution of misorientation angles between adjacent crystals. Such a texture is less ordered and less diagenetically stable than more constrained crystallographic textures of metazoans (Griesshaber et al. 2010; Cusack 2016; Päßler et al. 2018). Poorly ordered structure might have resulted in the relative instability of Rothpletzella skeletons and its potential dissolution in conditions of low redox potential.

We reconstruct that pyritization of the thalli proceeded after their burial, just below the sediment-water interface, in the upper part of the anaerobic sulphate reduction zone as the highest concentrations of iron needed for the process are found near the sediment surface (e.g., Canfield and Raiswell 1991). Presumably, the pyritization of the thalli proceeded almost simultaneously with their dissolution. The pyritization of thalli by large-sized $(>10 \mu \mathrm{m}$ in diameter) framboid and euhedral crystals may indicate that the Rothpletzella-encrusted shells were buried in the locally low $\mathrm{pH}$, highly dysoxic environment prevailing within the sediment 
(e.g., Brett et al. 1991; Marynowski et al. 2007; Bond and Wignall 2010). Interestingly, on the same brachiopod shells, certain other tiny encrusters originally having calcitic skeletons were pyritized. Here, the tiny foraminifers, and delicate 'stolons' and 'chambers' of some enigmatic ascodictyids, show distinct pyritization and loss of the external calcitic wall (Fig. 7). This additional evidence may support the above proposed view that the Rothpletzella sheaths may have also been originally calcareous, but under specific microenvironment within the sediment, the soft thalli underwent pyritization via bacterial sulphate reduction and their calcified sheaths were dissolved.

Although local conditions within the sediment might have been dysoxic, the rich epibenthic (including encrusters) assemblages noted in the upper Frasnian deposits of the Central Devonian Field point to the well-oxygenated conditions on the sea floor. Apart from various brachiopods, gastropods and corals, encrusting organisms commonly inhabiting the abundantly occurring brachiopod shells (Sokiran 2002) are represented by various groups, such as microconchids, cornulitids, foraminifera, bryozoans, auloporids, sphenothallids, ascodictyids or hederelloids (Zatoń and Krawczyński 2011; Zatoń et al. 2017). Such encrusting organisms are very characteristic for many other Devonian hard substrate communities (e.g., Alvarez and Taylor 1987; Bordeaux and Brett 1990; see also Taylor and Wilson 2003 for a comprehensive review). However, the fan-shaped Rothpletzella fossils reported here have never been encountered. Therefore, such organisms add another, this time probably non-animal, component to the whole assemblages. It is well known that fossil encrusting assemblages are dominated by those organisms which possessed well-mineralized skeletons and all those which were soft-bodied or lightly-mineralized have not been fossilized at all (e.g., McKinney 1996) or very sporadically (such as pyritized cyanobacteria, see Wilson and Taylor 2017), greatly reducing the real picture of the hard substrate community. The putative Rothpletzella colonies, reported here for the first time, belong to such encrusters 
which normally would not have fossilized, thus enriching the currently known Devonian encrusting assemblages in general.

Our putative Rothpletzella algae, similarly to foraminifera and enigmatic colonial ascodictyids (e.g., Olempska and Rakowicz 2014; Jarochowska and Munnecke 2014), occupied the lowest tier on the Frasnian brachiopod shells. The highest tier was occupied by trepostome bryozoans which commonly grew upward, especially at the shell commissure, and hydrozoan-like sphenothallids, which are solely preserved as phosphatized attachment bases. The middle tier was occupied by the rest of encrusters represented by microconchids, cornulitids, auloporids and hederelloids. However, among the encrusters, these algae were the only photosynthesizing organisms. Therefore, their presence on the substrates may indicate that the encrusting communities developed within the photic zone, an ecological factor which is difficult to prove in the fossil record without specific fossil indicators, such as algal or cyanobacterial borings (e.g., Vogel and Brett 2009) or their rare body fossils (e.g., Wilson and Taylor 2017).

It is further interesting that on the lower Famennian brachiopod shells from the Central Devonian Field in Russia, characterized by a similar preservation mode of the host brachiopods and encrusters, such algal fossils have not been encountered at all. A substantial faunal turnover and notable decline in abundance of encrusting communities have been observed across the upper Frasnian and lower Famennian in the area studied by Zaton et al. (2017), however, it is uncertain whether the disappearance of such algae on the lower Famennian shelly substrates resulted from palaeoenvironmental changes associated with the Frasnian-Famennian event itself or was it due to taphonomic factors. As Rothpletzella is known from the Famennian deposits of other areas (e.g., Feng et al. 2010; Weiner et al. 2018), it is reasonable to assume that their very low abundance on the upper Frasnian shells and absence on the lower Famennian shells in the area studied resulted from taphonomic reasons: 
only those thalli which entered a specific microenvironment had a chance to be pyritized and thus fossilized. Such reducing microenvironment in the sediment is uncommon in most shallow, well-oxygenated waters within the photic zone.

\section{Conclusions}

Despite the presence of a rich and diverse biota of encrusters preserved on the Upper Devonian brachiopod shells from the Central Devonian Field in Russia, careful searching revealed a new epibiont. Comparative analyses showed that the upper Devonian (upper Frasnian) encruster is most similar with respect to its morphology and growth mode to the problematicum Rothpletzella, which has only been recognized in thin sections so far. The width of its filaments is two- to threefold higher than those of all Rothpletzella described so far and exclude its potential cyanobacterial affinity. The Frasnian problematicum might have originally had calcitic sheaths surrounding the thalli, which are the primary remains of Rothpletzella known from the literature. However, due to locally low $\mathrm{pH}$, dysoxic microenvironment within the sulphate-reduction zone, the soft thalli underwent pyritization and their delicate calcified sheath dissolved. This may be supported by some of the associated encrusters having calcitic skeletons, which have also dissolved and underwent pyritization.

The presence of Rothpletzella algae provides a new, so far unrecognized, component in the Devonian encrusting communities inhabiting hard substrates, like brachiopod shells in the present case. Their absence in the lower Famennian deposits in the area studied likely resulted from taphonomic reasons rather than the Frasnian-Famennian extinction. 


\section{Acknowledgements}

The fieldworks in the Central Devonian Field during 2012 were supported by the National Science Centre (NCN, grant no. 2011/01/B/ST10/00576 to M.Z.). We thank to the following colleagues for help during the field works: Michał Rakociński, Tomasz Borszcz, Wojtek Krawczyński, Elena Sokiran and Andrey Zhuravlev. Axel Munnecke provided access to reference material in his thin section collection from Gotland, which is greatly appreciated. Mark Wilson and Steve Donovan, the journal referees, are thanked for constructive comments and useful corrections which improved the final version of the paper.

\section{References}

Anagnostidis K, Komárek J. 1990. Modern approach to the classification system of Cyanophytes. 5 - Stigonematales. Archiv fur Hydrobiologie, Suppl. 59:1-73.

Alvarez F, Taylor PD. 1987. Epizoan ecology and interactions in the Devonian of Spain. Palaeogeography, Palaeoclimatology, Palaeoecology. 61:17-31.

Arp G, Reimer A, Reitner J. 2001. Photosynthesis-induced biofilm calcification and calcium concentrations in Phanerozoic oceans. Science. 292:1701-1704.

Baird GC. 1976. Coral encrusted concretions: a key to recognition of a 'shale on shale' erosion surface. Lethaia. 9:293-302.

Baird GC. 1981. Submarine erosion on a gentle paleoslope: a study of two discontinuities in the New York Devonian. Lethaia. 14:105-122. 
Baird GC, Brett CE. 1983. Regional variation and paleontology of two coral beds in the Middle Devonian Hamilton Group of western New York. Journal of Paleontolog 57: $417-446$.

Bond DPG, Wignall PB. 2010. Pyrite framboid study of marine Permian-Triassic boundary sections: A complex anoxic event and its relationship to contemporaneous mass extinction. Geological Society of America Bulletin. 122:1265-1279.

Bordeaux YL, Brett CE. 1990. Substrate specific associations of epibionts on Middle Devonian brachiopods: Implications for paleoecology. Historical Biology. 4:203-220. Braga JC. 2003. Application of botanical taxonomy to fossil coralline algae (Corallinales, Rhodophyta). Acta Micropalaeontologica Sinica. 20:47-56.

Brett CE, Dick VB, Baird GC. 1991. Comparative taphonomy and paleoecology of Middle Devonian dark gray and black shale facies from western New York. In: Landing E., Brett CE, editors. Dynamic Stratigraphy and Depositional Environments of the Hamilton Group (Middle Devonian) in New York State, Part II. New York State Museum Bulletin. 469:5-36.

Brooke C, Riding R. 1998. Ordovician and Silurian coralline red algae. Lethaia. 31:185-195.

Canfield DE, Raiswell R. 1991. Pyrite formation and fossil preservation. In: Allison PSA, Briggs DEG, editors. Taphonomy: Releasing the Data Locked in the Fossil Record. Plenum Press, New York, p. 338-388.

Castenholz RW. 2001. General characteristics of the cyanobacteria. In: Boone DR, Castenholz RW, editors. Bergey’s Manual of Systematic Bacteriology, 2nd edn, vol. 1. Springer, New York, p. 474-487.

Cusack M. 2016. Biomineral electron backscatter diffraction for palaeontology. Palaeontology. 59:171-79. 
Feng Q, Gong Y-M, Riding R. 2010. Mid-Late Devonian calcified marine algae and cyanobacteria, South China. Journal of Paleontology. 84:569-587.

Filipiak P, Zbukova DV. 2006. Palynostratigraphy of the Frasnian-Famennian boundary deposits from the Central Devonian Field, western Russia and comparisons with adjacent areas. Review of Palaeobotany and Palynology. 138:109-120.

Golubić S, Hernandez-Marine M, Hoffmann L. 1996. Developmental aspects of branching in filamentous Cyanophyta/Cyanobacteria. Algological Studies. 83:303-329.

Griesshaber E, Neuser R, Schmahl W. 2010. The application of EBSD analysis to biomaterials: microstructural and crystallographic texture variations in marine carbonate shells. Seminarios de la Sociedad Española de Mineralogía. 7:22-34.

Gugger MF, Hoffmann L. 2004. Polyphyly of true branching cyanobacteria (Stigonematales). International Journal of Systematic and Evolutionary Microbiology. 54:349-357.

Hardie LA. 1996. Secular variation in seawater chemistry: An explanation for the coupled secular variation in the mineralogies of marine limestones and potash evaporites over the past 600 m.y. Geology. 24:279-83.

Hecker RF. 1983. Taphonomical and ecological pecularities of the fauna and flora of the Main Devonian field. Akademiya Nauk SSSR, Trudy Paleontologicheskogo Instituta 190, 1-141, 64 pl. (In Russian).

Hoffmann L, Komárek J., Kaštovský J. 2005. System of cyanoprokaryotes (cyanobacteria) state in 2004. Algological Studies. 117:95-115.

Jarochowska E., Munnecke A. 2014. The Paleozoic problematica Wetheredella and Allonema are two aspects of the same organism. Facies. 60:651-662.

Johnson JH. 1961. Limestone-building algae and algal limestones. Colorado School of Mines. $1-297$. 
Johnson JH. 1964. Lower Devonian algae and encrusting Foraminifera from New South Wales. Journal of Paleontology. 38:98-108.

Johnson JH, Konishi K, Rezak R. 1959. Studies of Silurian (Gotlandian) algae. Colorado School of Mines. 54:1-173.

Kershaw S. 1980. Cavities and cryptic faunas beneath non-reef stromatoporoids. Lethaia. 13: $327-338$.

Krings M, Klavins SD, Barthel M, Lausberg S, Serbet R, Taylor TN., Taylor EL. 2007. Perissothallus, a new genus for Late Pennsylvanian-Early Permian noncalcareous algae conventionally assigned to Schizopteris (aphleboid foliage). Botanical Journal of the Linnean Society. 153:477-488.

Leliaert F, Smith DR, Moreau H, Herron MD, Verbruggen H, Delwiche CF, De Clerck O. 2012. Phylogeny and molecular evolution of the green algae. Critical Reviews in Plant Sciences. 31:1-46.

Liow LH, Di Martino E, Voje KL, Rust S, Taylor PD. 2016. Interspecific interactions through 2 million years: Are competitive outcomes predictable? Proceedings of the Royal Society B. 283:20160981.

Liow LH, Di Martino E, Krzeminska M, Ramsfjell M, Rust S, Taylor PD, Voje KL. 2017. Relative size predicts competitive outcome through 2 million years. Ecology Letters. 20: 981-988.

Liu L, Wu Y, Yang H, Riding R. 2016. Ordovician calcified cyanobacteria and associated microfossils from the Tarim Basin, northwest China: systematics and significance. Journal of Systematic Palaeontology. 14:183-210.

Marynowski L, Rakociński M, Zatoń M. 2007. Middle Famennian (Late Devonian) interval with pyritized fauna from the Holy Cross Mountains (Poland): Organic geochemistry and pyrite framboid diameter study. Geochemical Journal. 41:187-200. 
Maslov VP. 1956. The fossil calcareous algae of the USSR. Transactions of the USSR Academy of Sciences: Geological Science Sections. 160:1-301. [In Russian.]

McKinney FK. 1996. Encrusting organisms on co-occurring disarticulated valves of two marine bivalves: Comparison of living assemblages and skeletal residues. Paleobiology. $22: 543-567$.

Neal ML, Hannibal JT. 2000. Paleoecologic and taxonomic implications of Sphenothallus and Sphenothallus-like specimens from Ohio and areas adjacent to Ohio. Journal of Paleontology. 74:369-380.

Nielsen SL. 2006. Size-dependent growth rates in eukaryotic and prokaryotic algae exemplified by green algae and cyanobacteria: comparisons between unicells and colonial growth forms. Journal of Plankton Research. 28:489-498.

Niklas KJ.1994. Plant allometry: the scaling of form and process. University of Chicago Press, $412 \mathrm{pp}$.

Niklas KJ. 1997. The evolutionary biology of plants. University of Chicago Press, $470 \mathrm{pp}$.

Olempska E, Rakowicz Ł. 2014. Affinities of Palaeozoic encrusting ascodictyid pseudobryozoans. Journal of Systematic Palaeontology. 12:983-999.

Palmer TJ, Fürsich FT. 1974. The ecology of a Middle Jurassic hardground and crevice fauna. Palaeontology. 17:507-524.

Päßler J-F, Jarochowska E, Bestmann M, Munnecke A. 2018. Distinguishing biologically controlled calcareous biomineralization in fossil organisms using Electron Backscatter Diffraction (EBSD). Frontiers in Earth Science. 6: 16. doi: 10.3389/feart.2018.00016.

Raven JA. 1999. The size of cells and organisms in relation to the evolution of embryophytes. Plant Biology. 1:2-12.

Riding R, Cope JCW, Taylor PD. 1998. A coralline-like red alga from the Lower Ordovician of Wales. Palaeontology. 41:1069-1076. 
Riding R, Soja CM. 1993. Silurian calcareous algae, cyanobacteria, and microproblematica from the Alexander terrane, Alaska. Journal of Paleontology. 67:710-728.

Ries JB. 2009. Effects of secular variation in seawater $\mathrm{Mg} / \mathrm{Ca}$ ratio (calcite-aragonite seas) on $\mathrm{CaCO}_{3}$ sediment production by the calcareous algae Halimeda, Penicillus and Udotea - evidence from recent experiments and the geological record. Terra Nova. 21:323339.

Rothpletz A. 1890. Über Sphaerocodium Bornemanni, eine neue fossile Kalkalge aus dem Raibler Schichten des Ostalpen. Botanisches Zentralblatt. 52:9.

Sandberg PA. 1983. An oscillating trend in Phanerozoic non-skeletal carbonate mineralogy. Nature. 305:19.

Schlögl J, Michalík J, Zágoršek K, Atrops F. 2008. Early Tithonian serpulid-dominated cavity-dwelling fauna, and the recruitment pattern of the serpulid larvae. Journal of Paleontology. 82:382-392.

Schneider CL. 2013. Epibiosis across the Late Devonian biotic crisis: a review. Proceedings of the Geologists' Association. 124:893-909.

Schulz-Vogt HN, Angert ER, Garcia-Pichel F. 2007. Giant Bacteria. In: Encyclopedia of Life Sciences, John Wiley \& Sons, published online 28 September 2007. doi:10.1002/9780470015902.a0020371.

Sokiran EV. 2002. Frasnian-Famennian extinction and recovery of rhynchonellid brachiopods from the East European Platform. Acta Palaeontologica Polonica. 47:339-354.

Stanley SM, Ries JB, Hardie LA. 2010. Increased production of calcite and slower growth for the major sediment-producing alga Halimeda as the $\mathrm{Mg} / \mathrm{Ca}$ ratio of seawater is lowered to a "Calcite Sea" level. Journal of Sedimentary Research. 80:6-16. 
Taylor PD, Vinn O. 2006. Convergent morphology in small spiral worm tubes ('Spirorbis') and its palaeoenvironmental implications. Journal of the Geological Society, London. $163: 225-228$.

Taylor PD, Wilson MA. 2003. Palaeoecology and evolution of marine hard substrate communities. Earth-Science Reviews. 62:1-103.

Taylor PD, Wilson MA. 2008. Morphology and affinities of hederelloid "bryozoans", p. 301309. In: Hageman SJ, Key MM, Jr, Winston JE (eds.), Bryozoan Studies 2007:

Proceedings of the 14th International Bryozoology Conference, Boone, North Carolina, July 1-8, 2007. Virginia Museum of Natural History Special Publication 15.

Verbruggen H, Ashworth M, LoDuca ST, Vlaeminck C, Cocquyt E, Sauvage T, Zechman FW, Littler DS, Littler MM, Leliaert F, De Clerck O. 2009. A multi-locus time-calibrated phylogeny of the siphonous green algae. Molecular Phylogenetics and Evolution. 50: $642-653$.

van Iten H, Cox RS, Mapes RH. 1992. New data on the morphology of Sphenothallus Hall: implications for its affinities. Lethaia. 25:135-144.

Vinn O, Kirsimäe K. 2015. Alleged cnidarian Sphenothallus in the Late Ordovician of Baltica, its mineral composition and microstructure. Acta Palaeontologica Polonica. 60: $1001-1008$.

Vinn O, Musabelliu S, Zaton M. 2018. Cornulitids from the Upper Devonian of the Central Devonian Field, Russia. GFF. https://doi.org/10.1080/11035897.2018.1505777. Vinn O, Wilson MA. 2012a. Epi- and endobionts on the late Silurian (early Pridoli) stromatoporoids from Saaremaa Island, Estonia. Annales Societatis Geologorum Poloniae. 82:195-200. 
Vinn O, Wilson MA. 2012b. Encrustation and bioerosion on late Sheinwoodian (Wenlock, Silurian) stromatoporoids from Saaremaa, Estonia. Carnets de Géologie. CG2012_A07: $183-191$.

Vogel K, Brett CE. 2009. Record of microendoliths in different facies of the Upper Ordovician in the Cincinnati Arch region USA: the early history of light-related microendolithic zonation. Palaeogeography, Palaeoclimatology, Palaeoecology. 281:124.

Weiner T, Weinerová H, Kalvoda J. 2018. Microproblematica, calcareous algae, and microbialites at the Frasnian-Famennian boundary interval in the Šumbera section (Moravian Karst, Czech Republic) and their significance in the context of the Kellwasser Crisis. Facies. 64:26. https://doi.org/10.1007/s10347-018-0538-z.

Wilson MA. 1985. Disturbance and ecologic succession in an Upper Ordovician cobbledwelling hardground fauna. Science. 228:575-577.

Wilson MA. 1986. Coelobites and spatial refuges in a lower Cretaceous cobble-dwelling hardground fauna. Palaeontology. 29:691-703.

Wilson MA. 1998. Succession in a Jurassic marine cavity community and the evolution of cryptic marine faunas. Geology. 26:379-381.

Wilson MA, Taylor PD. 2001. Palaeoecology of hard substrate faunas from the Cretaceous Qahlah Formation of the Oman Mountains. Palaeontology. 44:21-41.

Wilson MA, Taylor PD. 2014. The morphology and affinities of Allonema and Ascodictyon, two abundant Palaeozoic encrusters commonly misattributed to the ctenostome bryozoans. In: Rosso A, Wyse Jackson PN, Porter J, editors. Bryozoan Studies 2013. Studi trentini di scienze naturali. 94:259-266. 
Wilson MA, Taylor PD. 2017. Exceptional pyritized cyanobacterial mats encrusting brachiopod shells from the Upper Ordovician (Katian) of the Cincinnati, Ohio, region. Palaios. 32:673-677.

Wisshak M. 2017. Taming an ichnotaxonomical Pandora's box: revision of dendritic and rosetted microborings (ichnofamily: Dendrinidae). European Journal of Taxonomy. 390: $1-99$.

Wisshak M, Titschack J, Kahl W-A, Girod P. 2017. Classical and new bioerosion trace fossils in Cretaceous belemnite guards characterised via micro-CT. Fossil Record. 20:173-199.

Wood A. 1948. „Sphaerocodium”, a misinterpreted fossil from the Wenlock Limestone.

Proceedings of the Geologists’ Association. 59:9-22.

Wray JL. 1977. Calcareous algae. Developments in paleontology and stratigraphy, 4. Elsevier, New York, 184 pp.

Zapalski M. 2005. Paleoecology of Auloporida: an example from the Devonian of the Holy Cross Mts., Poland. Geobios. 38:677-683.

Zapalski MK, Clarkson ENK. 2015. Enigmatic fossils from the Lower Carboniferous Shrimp Bed, Granton, Scotland. PLoS ONE. 10(12):e0144220, doi:10.1371/journal.pone.0144220

Zatoń M, Krawczyński W. 2011. Microconchid tubeworms across the upper Frasnian - lower Famennian interval in the Central Devonian Field, Russia. Palaeontology. 54:1455-1473.

Zatoń M, Machocka S, Wilson MA, Marynowski L, Taylor PD. 2011. Origin and paleoecology of Middle Jurassic hiatus concretions from Poland. Facies. 57:275-300.

Zatoń M, Zhuravlev AV, Rakociński M, Filipiak P, Borszcz T, Krawczyński W, Wilson MA, Sokiran EV. 2014. Microconchid-dominated cobbles from the Upper Devonian of Russia: opportunism and dominance in a restricted environment following the Frasnian- 
Famennian biotic crisis. Palaeogeography, Palaeoclimatology, Palaeoecology. 401:142153.

Zatoń M, Borszcz T, Berkowski B, Rakociński M, Zapalski MK, Zhuravlev AV. 2015. Paleoecology and sedimentary environment of the Late Devonian coral biostrome from the Central Devonian Field, Russia. Palaeogeography, Palaeoclimatology, Palaeoecology. 424:61-75.

Zatoń M, Borszcz T, Rakociński M. 2017. Temporal dynamics of encrusting communities during the Late Devonian: a case study from the Central Devonian Field, Russia. Paleobiology. 43:550-568.

Zatoń M, Zapalski M, Berkowski B, Wrzołek T. 2018. Cryptic encrusting communities in a Middle Devonian mesophotic paleoenvironment of the Holy Cross Mountains, Poland. Palaeogeography, Palaeoclimatology, Palaeoecology. 501:82-91.

Zatoń M, Vinn O. 2011. Microconchids. Geology Today. 27:236-239.

\section{Figures:}




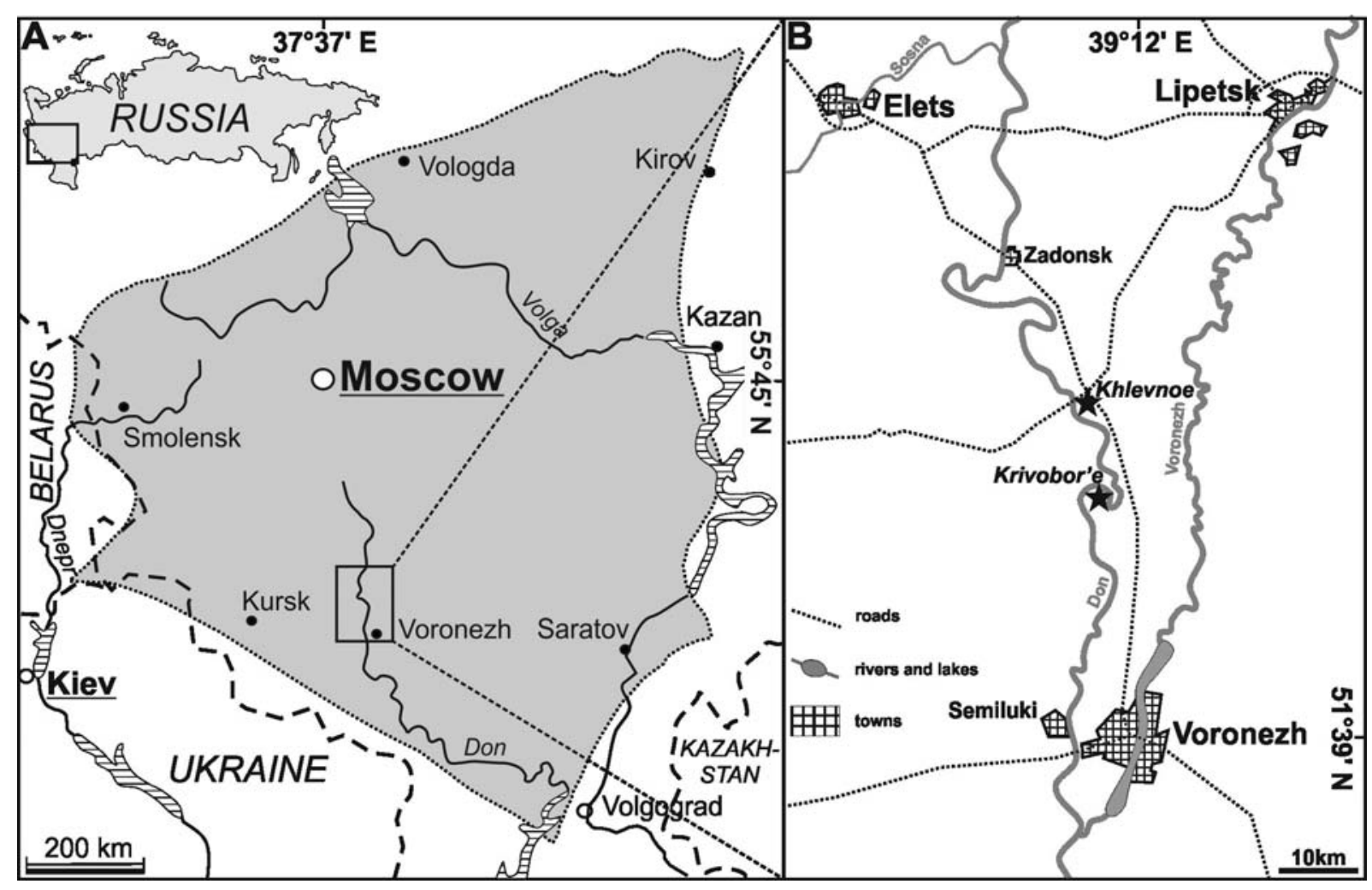

Figure 1. Locality of the studied area. A. Geological sketch-map of the Central Devonian

Field with an area sampled indicated. B. Locality of the investigated Upper Devonian (upper

Frasnian) outcrops at Khlevnoe and Krivobor'e (slightly modified after Sokiran [2002] and Zatoń and Krawczyński [2011]). 


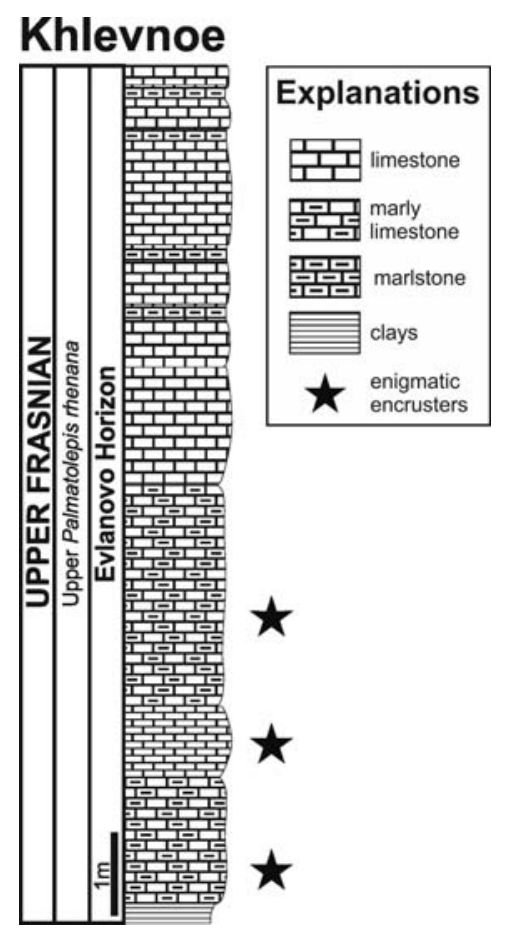

Figure 2. Lithostratigraphic section of the upper Frasnian deposits outcropped at Khlevnoe locality (after Sokiran [2002], Filipiak and Zbukova [2006], Zatoń and Krawczyński [2011] and Zatoń et al. [2017]). 

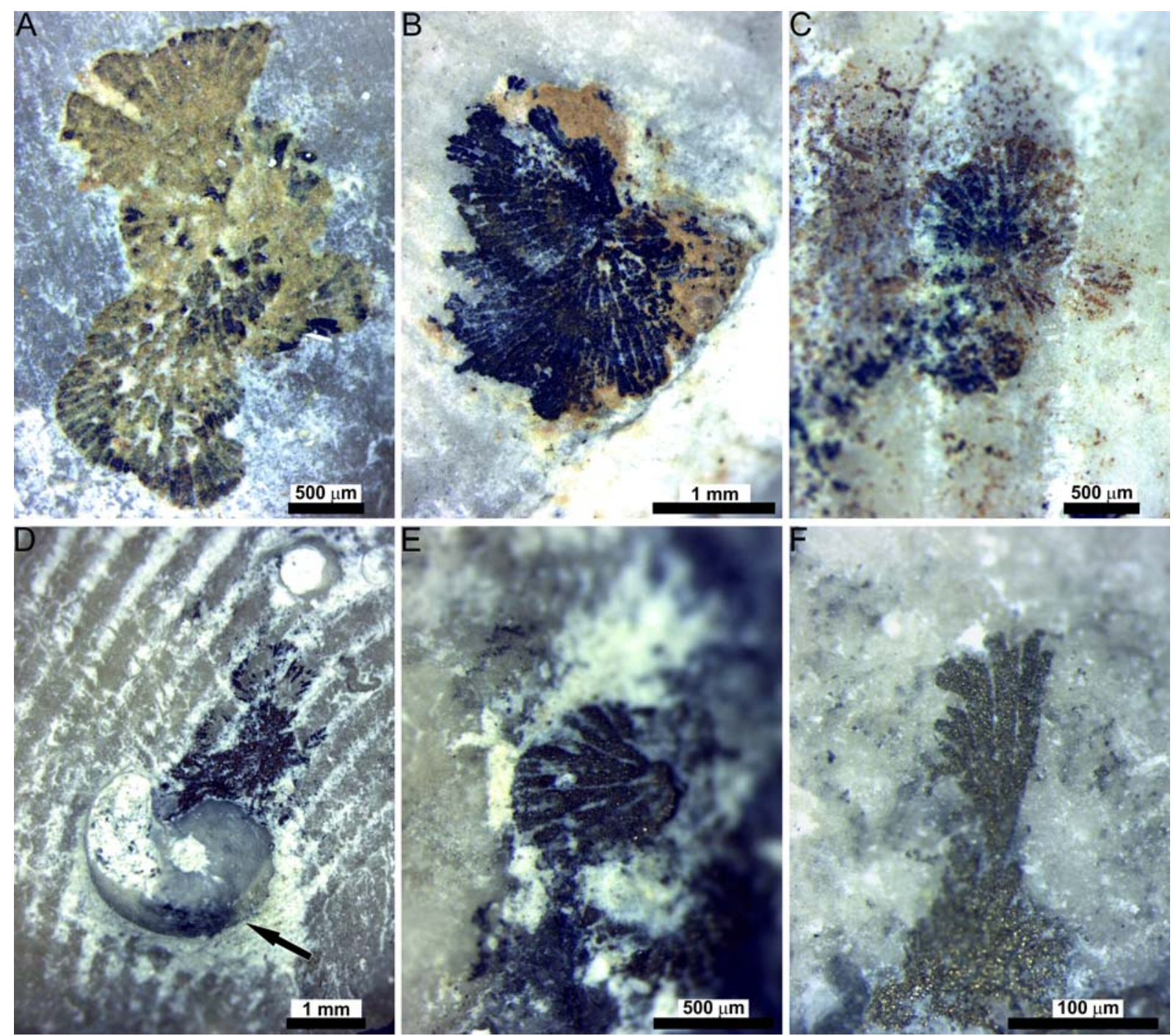

Figure 3. Macrophotographs of the Upper Devonian encrusting fossils investigated,

Khlevnoe locality, Russia. A-B. Larger colonies showing distinct fan-shaped lobes, GIUS 4-

3681/Kh-s4/39 and GIUS 4-3681/Kh-s1/251, respectively. C. A specimen with preserved central part of the colony, GIUS 4-3681/Kh-s1/75. D. A colony encrusting the associated microconchid tubeworm (arrow), GIUS 4-3681/Kh-s1/79. E-F. Fan-shaped lobes showing distinct bifurcation of the pyritized branches, GIUS 4-3681/Kh-s2/50 and GIUS 4-3681/Khs2-50, respectively. 





Figure 4. ESEM microphotographs of selected Upper Devonian encrusting fossils

investigated, Khlevnoe locality, Russia. A-B. Fan-shaped colony showing a putative pointed origin (arrowed in A) and distinct bifurcating branches (B), GIUS 4-3681/Kh-s1/251. C.

Colony encrusted by branches probably belonging to a separate specimen (white arrow), and microconchid tubeworm (black arrow). D. Enlargement of the branches showed in C, preserved by pyrite euhedral crystals and framboids, GIUS 4-3681/Kh-1/135. E-F. Partially preserved colony showing well-developed branching patterns (F), GIUS 4-3681/Kh-s2/50. GH. Single lobe showing distinct branching and preservation mainly by pyrite framboids $(\mathrm{H})$, GIUS 4-3681/Kh-s2/18.
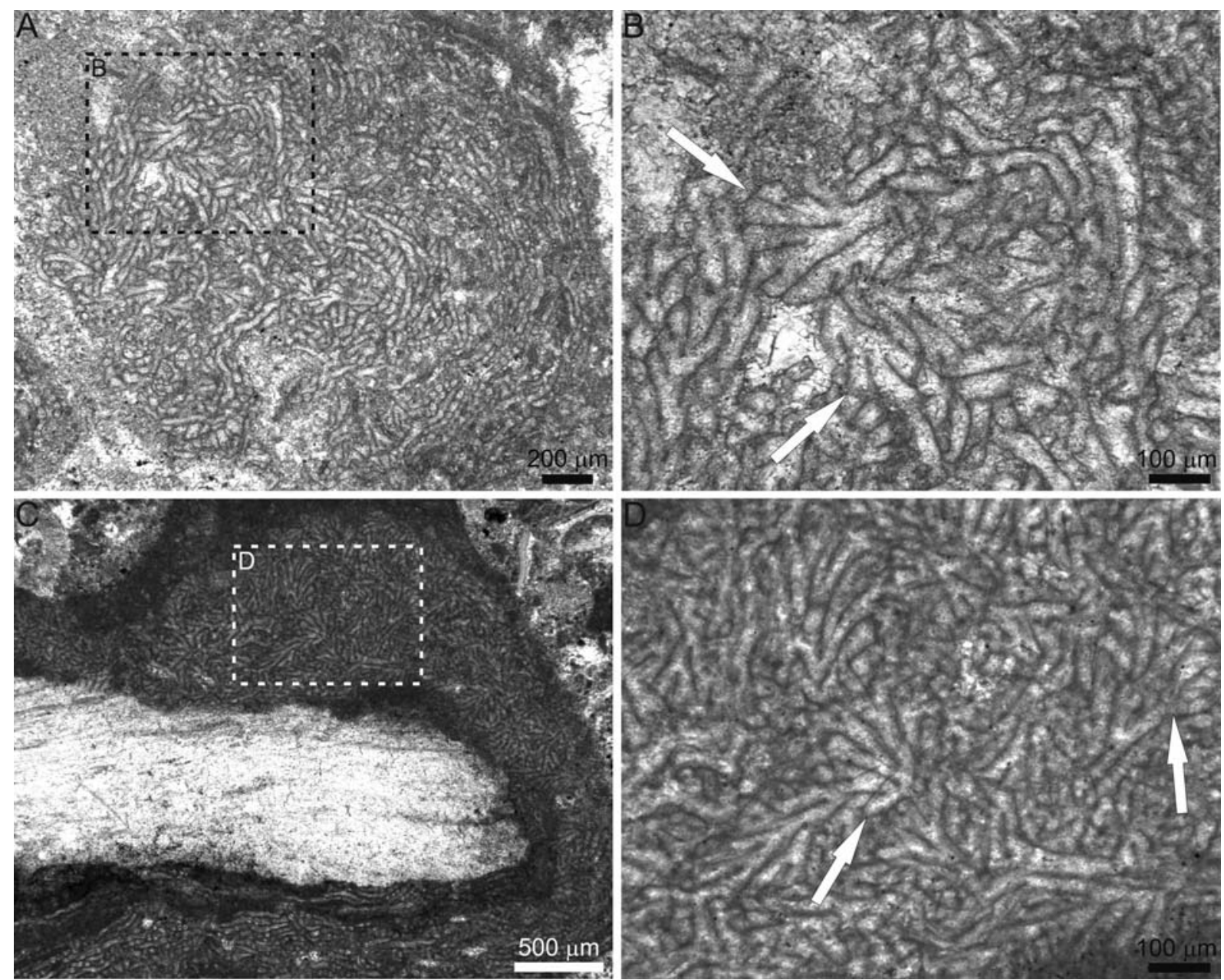

Figure 5. Thin section images of Rothpletzella from the Silurian of Gotland, Sweden. A-B.

Thick coating (A) of Rothpletzella showing similar morphologies and branching pattern (arrowed in B) as those seen in Upper Devonian colonies from Russia, AM124. C-D. thick 
coating of Rothpletzella forming an oncoid cortex (A), where particular colonies show distinct branching patterns (arrowed in B), AM124.
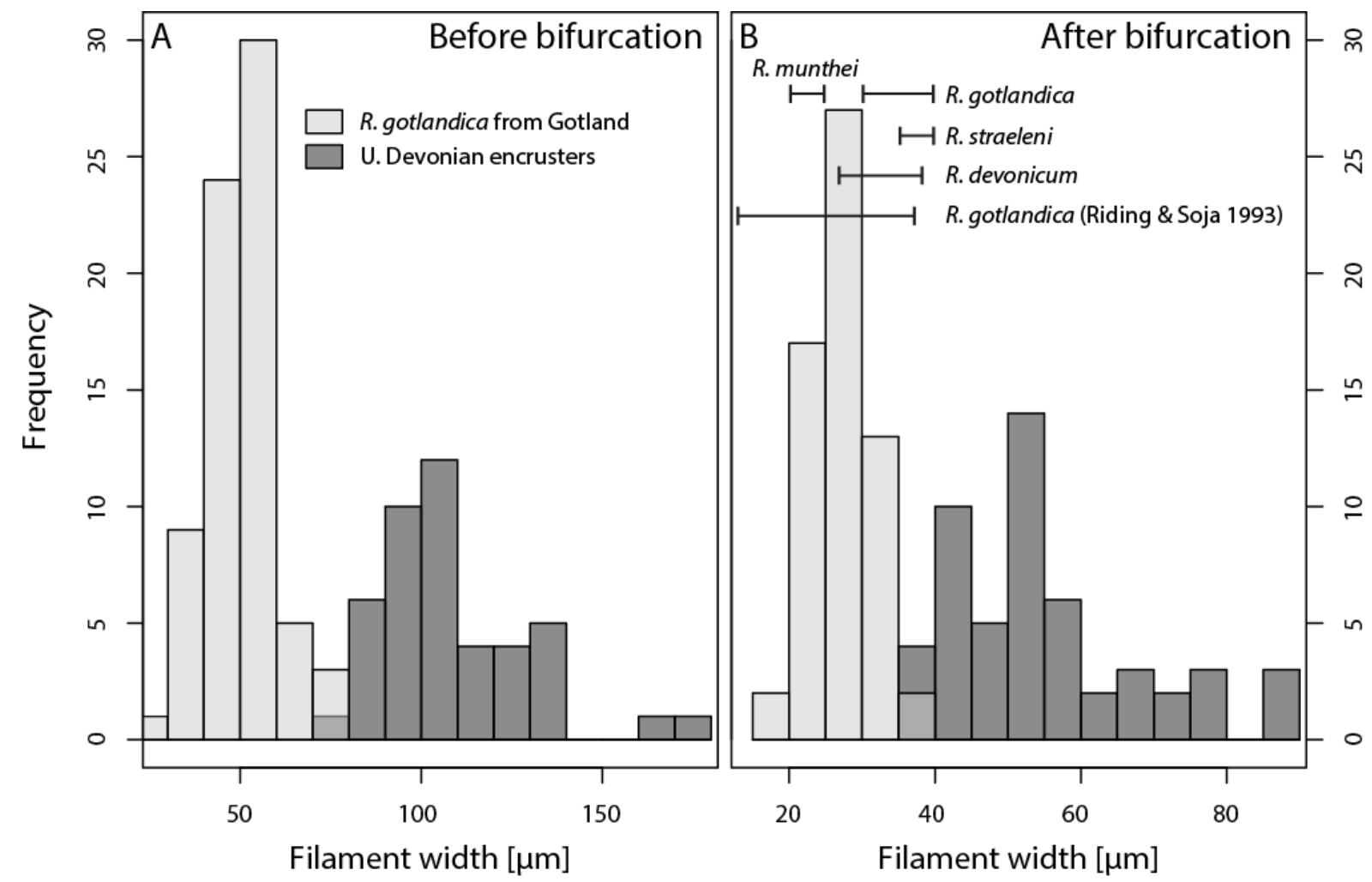

Figure 6. Histograms showing the distribution of the filament (branch) width in Silurian Rothpletzella and Upper Devonian forms.
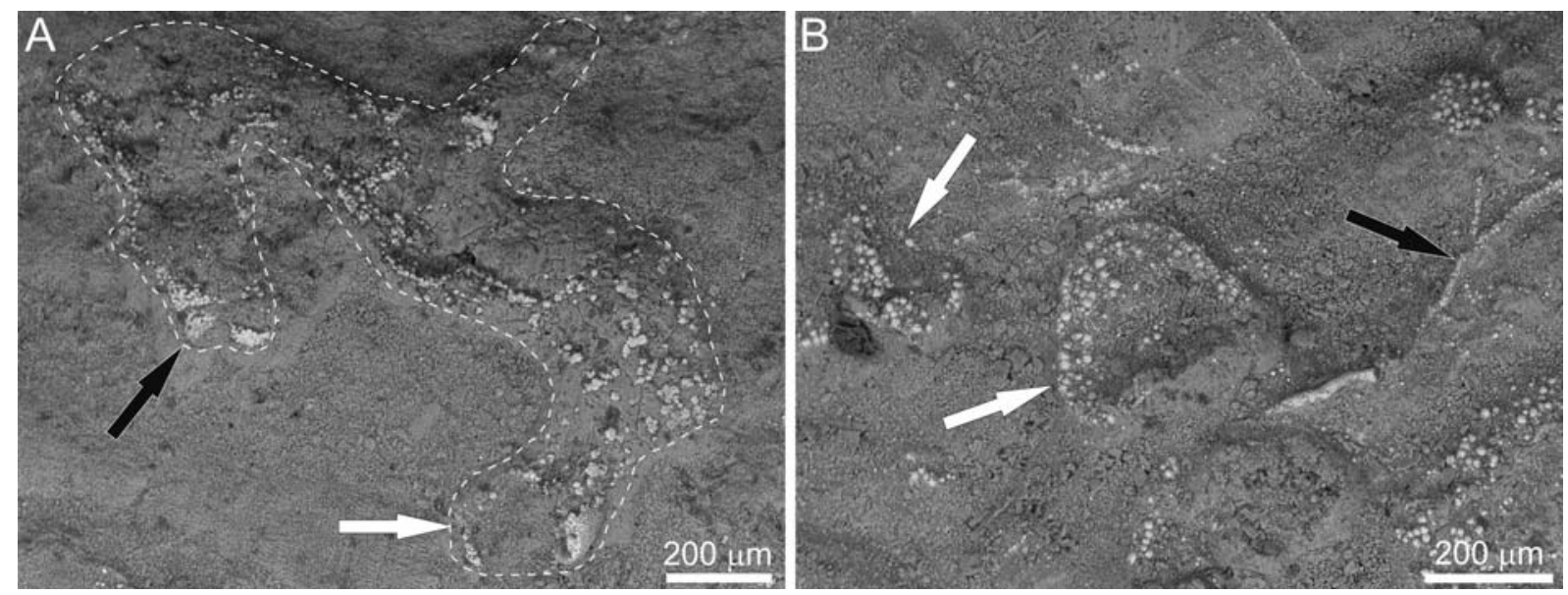

Figure 7. Pyritization of other associated encrusters from Khlevnoe locality, Russia. A.

Encrusting foraminifer showing dissolved calcitic wall which was pyritized in some places.

Black arrow points to the test origin and the white arrow points to the foramen. Dotted line 
outlines the specimen. B. Ascodyctyid encrusting the same brachiopod host, showing pyritized 'chambers' (white arrows) and thin 'stolons' (black arrow), GIUS 4-3681/Kh-s2/18.

Appendix 1. Measurements of Upper Devonian specimens and Silurian forms of Rothpletzella. 